\title{
'What Shall We Sing Now, Amir?' Developing a Voice through Translanguaging Pedagogy- An Ethnographic Research and Professional Training Project in Day-Care Centers and Schools
}

\section{Julie A. Panagiotopoulou and Maria J. Hammel}

\section{Abstract}

With the aim of promoting inclusion and social justice in education, a new project supports (multilingual) professionals who address their own pedagogical practice of counteracting the disadvantages multilingual children face within a monolingual norm in Germany. The presentation of the project highlights how translanguaging as a pedagogy gives language-minoritized children a voice and as a sensitizing concept can be utilized for the analysis of project data and especially of ethnographic observations of learning and teaching practices.

\section{Keywords}

Translanguaging $\cdot$ Professionalization $\cdot$ Ethnography $\cdot$ Multilingualism

\footnotetext{
J. A. Panagiotopoulou $(\bowtie) \cdot$ M. J. Hammel University of Cologne, Cologne, Germany e-mail: a.panagiotopoulou@uni-koeln.de

M. J. Hammel

e-mail:m.hammel@uni-koeln.de
}

(C) The Author(s) 2020

J. A. Panagiotopoulou et al. (eds.), Inclusion, Education and

Translanguaging, Inklusion und Bildung in Migrationsgesellschaften, https://doi.org/10.1007/978-3-658-28128-1_12 


\section{Introduction}

This contribution focuses on an ethnographic research and professional training project for (future) educators and teachers in Cologne (Germany) titled "Translanguaging Pedagogy in Multilingual Day-care Centers and Schools" (TranslaPed), led by Julie A. Panagiotopoulou, that aims to support multilingual professionals who intensively deal with shaping their own pedagogical practice in a more inclusive way and, thus, contribute to social justice. After a brief critical review of educational language policy in German day-care centers and schools (2.), the theoretical framework of the project that was started in 2018 at the University of Cologne will be discussed under the question how translanguaging can be utilized as a sensitizing concept for the analysis of ethnographic observations of learning and teaching practices (3.). Furthermore, the design of the main project, as well as the research questions of Maria J. Hammel's dissertation will be presented using an example from a daily pedagogical routine showing how language-minoritized children "develop a voice through translanguaging" (4.).

\section{Educational Language Policy in Germany}

Germany's official monolingual language policy has become particularly apparent in recent years under the conditions of (forced) migration and the considerable challenge of including refugee children in day-care centers and schools. The current language policy regarding newcomers aims to integrate them through language assimilation, and by doing so (re)produces the monoglossic hegemony in Germany (Panagiotopoulou 2020; Panagiotopoulou and Rosen 2018). Although many newly arrived students are already multilingual, they are often approached by monolingual authorities and educational institutions as if they had no language resources at all. Utilizing ethnographic studies in so-called preparatory classes for newcomers in Cologne, we were able to reveal, in particular, how young children who grow up in multilingual families and/or have become literate in more than one language (e.g. in Arabic and English) before their (forced) migration are often stigmatized as "zero-language speakers" (in German: "Nullsprachler"), possessing only non-lingual resources (Panagiotopoulou et al. 2020).

Even multilingual children who grow up in Germany and attend day-care for the first time are also-metaphorically speaking-newcomers, as they and their parents are officially confronted with this language policy reproducing a strictly monoglossic hegemony for the first time. In particular, children from immigrant families are assumed to not being able to speak German, especially "native" 
and "academic German", due to their multilingualism (for a critical view on monolingual language ideologies in day-care centers and schools see Montanari and Panagiotopoulou 2019). These children's language practices are usually regarded as problematic, their language skills as insufficient for the Germanspeaking day-care center, while the solution offered for this self-made problem is a separate language support, without taking into account the competences in home languages. However, this is very likely to achieve the opposite effect, since restricting children's multilingual repertoire in educational institutions puts young learners at a disadvantage by preventing them from using all their available resources and strategies for learning and by stigmatizing them as "semilinguals" (Panagiotopoulou 2017a). This language policy implicitly requires that all language users (even those who live multilingually) should speak "German only" in a German educational context. In (formally) monolingual day-cares and schools, members of the educational staff, even those who act multilingually in their own everyday lives, tend to communicate monolingually with multilingual colleagues, students and parents and hence to exclude "other" languages (Panagiotopoulou and Zettl 2020) or to silence the voices of "others", e.g. of Arabic-speaking newcomers in preparatory classes (Panagiotopoulou et al. 2020).

One of inclusive pedagogy's main principles, which originated long before the debate on inclusion in Germany even started, may be formulated as treating "family language worlds" of all children [and educators] with respect in educational institutions regardless of whether they consist of "standard", "dialectal" or "mixed" registers (List 2004, p. 133). Nowadays and although the issue of multilingualism is being explicitly addressed in the German educational guidelines for early childhood language training, the focus remains mainly on "the promotion of the [academic] German language" (Lengyel and Salem 2018, p. 443 f.). Primarily "migrant languages" such as Arabic, Turkish, Russian, Italian or Greek tend to be marginalized and each of them neglected as a "non-academic language" (as opposed to the "language of education", in German: "Bildungssprache"), whereas only selected languages with elite prestige such as English are offered in special (private) bilingual day-care centers in the form of foreign language acquisition. Therefore, this language policy encourages the exclusion of home languages, thus contradicting the values of inclusive multilingual pedagogy (Panagiotopoulou 2016).

This educational language policy is also transposed onto the landscape of further education for (early) pedagogical staff, as the current study by Samuel Jahreiß (2018) unveils. The reason appears to be that the "understanding of multilingual education, which is aimed at all children in day-care centers in order to promote an increase in competence in all spoken languages, has not yet become 
part of further training for pedagogical specialists" (Jahreiß 2018, p. 52). Multilingual educators in Cologne day-care centers often express skepticism towards the implementation of multilingual education regardless of whether they are themselves living multilingually, which can be attributed to underdeveloped pedagogical concepts (Roth et al. 2018). This result is particularly problematic because "early childhood multilingual education", which is also understood as being inclusive, "lives off multilingual role models" in education and family contexts (Chilla and Niebuhr-Siebert 2017, p. 97; Uçan 2018).

In pedagogical practice the opposite is the case: Restricting young children's multilingual repertoires in the context of monolingual educational institutions puts many children in Germany at a disadvantage by preventing them from using all their available multimodal, linguistic and semiotic resources and strategies for learning, as they usually do. This is an important reason why questioning monolingual language policies and teaching practices through ethnographic observations of multilingual and translingual children's learning practices in German day-care centers and schools is of paramount relevance to promote social justice in education.

\section{Translanguaging as a Theoretical Framework: Promoting Social Justice in Education Contexts}

Multilingual children do not use autonomous languages or linguistic systems but make use of their whole linguistic repertoire (García 2009), e.g. "their words" (such as "uzeug" or "aeplano", see the following excerpt) often without consideration for conventional language boundaries. In order to communicate with other multilinguals, even very young children combine the accessible linguistic elements into an integrated whole which can always be adjusted to the situation and their interlocutor's repertoire. This might seem, to a certain extent, extraordinary from the external perspective of a monolingual language user. However, from the perspective of multilingual children, this dynamic language usage is authentic, legitimate and conducive to learning. In order to make this transparent, ethnographic studies in day-care centers can be crucial. To analyze such observations and make them comprehensible for the participating educators, many scholars in different, also German speaking countries use translanguaging as a "sensitizing concept" (Charmaz 2014, p. 117), (for an overview of ethnographic studies see Montanari and Panagiotopoulou 2019). We would like to illustrate this with an excerpt from the field study "Lena" (Panagiotopoulou 2016): 
Lena, a two and a half-year-old child from a German-Greek-speaking family looks at me and says "uzeug" while viewing a picture book.

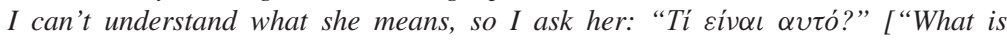
that?"]

Lena asks back: "aplano”?

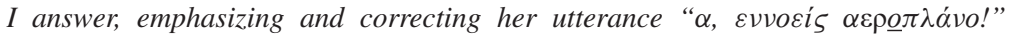
["Ah, you mean aeroplano!"] to signal that I now understand what she meant (namely in Greek "aeroplano", pronounced by Lena as "aplano”, in German "Flugzeug”, pronounced as "uzeug”).

Lena nods so as to confirm, while also repeating, emphasizing and correcting her own utterance: "aeplano!"

Ethnographic studies may provide scholars and educators with a deeper insight into the practice of translanguaging by young children like Lena who tend to cross conventional language boundaries despite the monolingual language policies of the German educational institution. In the course of professional training for pre-service teachers and educators, these ethnographic observations may respond to such important questions as: How do multilingual children use their entire linguistic repertoire to communicate and learn (e.g. see above: What is an "uzeug")? Taking observations on translanguaging into account, this may contradict the traditional understanding of languages as autonomous, clearly defined systems (L1, L2, L3 etc.) which are learned or acquired by individuals as monolingual codes in an additive manner ( $\mathrm{L} 1+\mathrm{L} 2+\mathrm{L} 3$ etc.). Ethnographic observations of language practices also entail questioning the ideology that multilingual adults (like Lena's interlocutor in the observation above) allegedly do not "mix" their languages and any kind of "language mixing" presents an irregularity and a deviation from the monolingual norm. Ethnographic research projects in (officially) mono- or multilingual regions of the globe and in the context of (formally) mono- and multilingual educational institutions for children, adolescents and adults suggest the opposite: despite the ability to act monolingually in monolingual settings, authentic language usage of multilingual individuals remains flexible and dynamic (Creese 2017).

Furthermore, translanguaging is also "a practical theory of language" (Li Wei 2018 , p. 9) which underscores "the necessity to bridge the artificial and ideological divides between the so-called sociocultural and the cognitive approaches to Translanguaging practices". As Li expounds, multilingual children do not disassemble their complex linguistic repertoires, in order to pick just "one namable language" or register for communication, because even when they act monolingually in specific situations, when they are in a "monolingual mode", their thinking process still takes place "beyond language, and thinking requires the use of a variety 
of cognitive, semiotic, and modal resources" (Li Wei 2018, p. 18). In the abovementioned excerpt, we see how Lena, a two and a half year old child, implements elements from her entire linguistic repertoire to communicate with her interlocutor while she develops her bilingualism: "young kindergarteners use translanguaging for [...] metafunctions", e.g. "to construct meaning within themselves" or "to mediate understandings among each other" (García and Li Wei 2014, p. 82). With her translation "a(ero)plano", Lena ensures that her original utterance "uzeug" is recognized as "airplane" by her interlocutor. Furthermore, with her improved second emphasized attempt ("aeplano"), Lena also approaches the target language utterance ("aeroplano") by adding an element and it is precisely this intentional emphasis that renders a variety of linguistic and semiotic resources and her dynamic, translingual learning process observable. In this interaction Lena demonstrates knowledge and at the same time she creates new meaning, since "[t]ranslanguaging [...] enabled the learning to take place" (García and Li Wei 2014, p. 82). Similarly, by using observations from a bilingual kindergarten in the USA, García (2011, p. 47) found that the most prevalent use of translanguaging by young children was to co-construct meaning, both with others and within themselves.

If ethnography "has enabled the voices" of children, like Lena, "to be heard" (James 2001, p. 255; Panagiotopoulou 2013, p. 771), through professional trainings based on such ethnographic observations (future) educators and teachers could be enabled to hear the voices of (emergent) bi/multilinguals, more precisely, to support them in "developing a voice through translanguaging" (García and Li Wei 2014, p. 108) by critically reflecting on (their own) traditional conceptions of autonomous languages and monolingual pedagogical practices. Especially if they intend to support young bi/multilingual children comparable to Lena by including "all the language practices of all students in a class" (García and Li Wei 2014, p. 66, original emphasis) and encouraging them "to learn within and across languages" (List 2010, p. 10), educators challenge their own teaching as the concept of translanguaging "has the potential to change the nature of learning, as well as of teaching" (García and Li Wei 2015, p. 229).

As a sensitizing concept translanguaging redirects our attention from the separate namable languages and varieties existing as autonomous systems to the authentic language practices (the languaging) of multilinguals. As a pedagogy translanguaging has been put into practice in schools and day-care centers already (García et al. 2017; Seltzer et al. see this volume), which bears implications for educational (language) policy: "the voices of Others come to the forefront, relating Translanguaging to criticality, critical pedagogy, social justice, and the linguistic human rights agenda" (Li Wei 2018, p. 24; García and Flores 2012). 


\section{$4 \quad$ Translanguaging Pedagogy in Multilingual Day-Care Centers and Schools: A Research and Professional Training Project in Cologne}

In this section we will briefly depict how the intention of the project to empower and support (future) teachers and educators utilizing the concept of translanguaging pedagogy arose and how it led to the current design. Following the publication of the expertise "Multilingualism in Childhood" (Panagiotopoulou 2016) published as part of the "Further Education Initiative" of the DJI (German Youth Institute) early childhood educators and teachers were informed in detail about the "multilingual turn" (Conteh and Meier 2014), the approaches of "multilingual pedagogies" (García and Flores 2012), as well as the German concept of "multilingual didactics" (Reich and Krumm 2013) and the "possible perspectives for a reorientation of language pedagogical practice" and "concepts of an inclusive pedagogy [...], such as Translanguaging (García and Li Wei 2014; García 2009)" (Panagiotopoulou 2016, p. 24). Two bilingual (German-Italian and German-English) day-care centers based in Cologne approached the author of the expertise at the University of Cologne on their own initiative and asked for concrete support in "changing structures that have become entrenched in daycare life" (e.g. strict language separation according to the immersion model and striving for "elite multilingualism") and for assistance in opening up new language support programs "for immigrant, language-minoritizedchildren" through a further training on translanguaging.

Furthermore, a third day-care center introduced itself to us at a city networking event regarding multilingualism in day-care centers. Subsequently, this kindergarten, which already utilized the term translanguaging (also as a result of the above-mentioned publication) in its language training program to declare its orientation towards lived and authentic multilingualism (in German, Arabic and Turkish) also expressed a desire for further training. This apparent need for further training in translanguaging, which was generated and formulated directly from early pedagogical practice, gave rise to the idea of initiating a superordinate project that would offer the unique opportunity to document the beginning of the implementation of translanguaging pedagogy in the Cologne area, to develop a further training concept for the implementation of translanguaging in pedagogical everyday life in German day-care centers. ${ }^{1}$

\footnotetext{
${ }^{1}$ In the meantime, primary schools in Cologne were also involved in the project, however, the present contribution focuses on day-care centers.
} 
The process of developing a training concept on translanguaging for day-care centers will be accompanied by Maria J. Hammel's dissertation project: Through constant gathering, documentation and comparison of ethnographic data (interviews and observations) we will be able to create a multi-sited perspective on if and how different day-care centers in Cologne overcome monolingual ideologies and practices, and adopt a more inclusive and multilingual approach. To that aim the accompanying research is pursuing the following questions:

1. What expectations do the participants have of a professional training on translanguaging? To what extent can an implicit striving for "elite multilingualism" in contrast to "marginalized multilingualism" be discerned?

2. What experiences, perceptions and deeper insights do the participants have during the training and how do they compare to their expectations?

3. Which language ideologies do they overcome and/or which translanguaging practices do they implement in their practice on the basis of further training?

4. What conclusions do they draw at the end of the training?

The goals of the dissertation project are to be achieved with the help of various documentation and survey instruments in accordance with "Constructing Grounded Theory" (Charmaz 2014). The instruments are briefly presented in the following.

In relation to the addressees of the training (educators, day-care center managers): narrative-generating expert interviews are conducted a few days before and immediately after a workshop to collect data concerning explicit and interpretative knowledge (Bogner et al. 2009). The main aim of the pre-interviews is to clarify the expectations of the participants. The post-interviews are intended to reflect the effects of the training and to draw conclusions about possible changes in the interviewees' attitudes towards translanguaging. In addition, for the student ethnographers involved in the preparation and implementation of the project and the project leader and trainer, guided interviews (Bohnsack et al. 2018, p. 151 f.) are being used, which are also conducted before and after each workshop.

In this training concept, ethnographic observations are collected by student ethnographers several weeks before the first training unit. The ethnographers, who are future educators and teachers, are in the final phase of their (master) studies and will be trained and accompanied in a weekly ethnographic research workshop simultaneously with the ongoing survey. This will help assess an ethnographic attitude during the observation process (Panagiotopoulou 2017a) as well as the production of thick descriptions (Geertz et al. 1983) and possibly to sharpen the further focus of observation by a first common coding of selected 
sequences (Charmaz 2014). The collected data also serve as an empirical basis for the student ethnographers' final master theses, which generate a great usability and efficiency of the survey for various purposes.

Certain sequences, like the following example, were then specifically selected from the available observation protocols to give the observed educators the opportunity to reflect on their own pedagogical practice during the workshops.

All children and educators [sit] around the table and start the morning circle. Amara says, "Yalla, alle Kinder erstmal psssscht" ["Yalla, all children first psssh"] and puts her finger on her mouth. Some of the children do the same until finally all are quiet. Then they begin to recite an Arabic prayer song, "Bismillah", and gesture to it. First, they make a bowl with their hands, then they wipe their face with their hands. When the song ends, Amara asks, "Was sollen wir jetzt singen, Amir?" ["What shall we sing now, Amir?"] Amir says a little quieter: "Alle meine Entchen" ["All my little ducklings"] (a German children's song). Amara repeats: "Alle meine Entchen? Ok!" ["All my little ducklings? Ok!"]. They start to alternately knock twice on the table and clap their hands once and sing "Alle meine Entchen" with the melody from the song "we will rock you" (from the rock band Queen). The children all join in and knock loudly on the table and clap their hands.

(Day-Care Center Arkadaş, 13.12.2018; ethnographer F. Kamphuis; the names of the day-care center, educators and children are pseudonymized and are subject to data protection guidelines).

In this short example of a daily ritual of the researched day-care center we see a "meaningful performance" (Li Wei 2011, p. 1223). The starting statement "Yalla, all children first psssscht" regularly invites all children to participate in the daily pedagogical routine through translanguaging, which "opens up a space of resistance and social justice" (García and Li Wei 2014, p. 115), including also language practices of "minoritized" children and educators. What is special here is the fact that the utterance begins with an Arabic word generally known in the field, continues in German and ends with an onomatopoetic interjection, which is accompanied by the associated gesture ("puts a finger on the mouth"). These diverse, verbal and non-verbal signs enable all children to understand the request and to independently follow and participate in the group event. At the same time, it is signalized that multimodality and migration-related multilingualism are welcome within this particular action, which makes this morning circle "a translanguaging space" for its participants.

Following García and Li Wei, translanguaging opens up trans-spaces capable of stressing the sociopolitical order (García and Li Wei 2014, p. 137), which in this case would be the monolingual norm that predominates German day-care centers 
and also the expectation towards children to act "only in German". The children here experience that songs can be sung in different and also in their own home languages and that they (when asked by the educator) are given the opportunity to decide about the content of the morning circle themselves, as shown by the threeyear-old child named Amir. That morning, he makes the decision that a traditional German song should now follow a traditional Arabic song, namely "Alle meine Entchen", and thus both languages-Arabic and German - are used in a non-hierarchical way. By singing the song to an internationally known, modern rock melody, this "act of translanguaging" irritates the monoglossic hegemony again and identifies the observed situation as the practice of a creative and multimodal transspace and as "a social space" for multilingual, yet language-minoritized educators and children "by bringing together different dimensions of their personal history, experience and environment [...] into one coordinated and meaningful performance". (Li Wei 2011, p. 1223).

The fact that this transformative moment is initiated by the educators on a daily basis, as the ethnographic observations have shown, proves that the practice of a translanguaging space is not an accidental, special competence of individual multilingual educators in the observed day-care center, but has already been institutionalized as part of a pedagogical concept (and that translanguaging plays a central role in the educators' professional practice). ${ }^{2}$

The training session in which the educators were confronted with the scene above was recorded and later transcribed, as were all future training sessions. As can be seen from the transcript of this workshop, one of the participants explained that the translanguaging morning circle "encourages the participation of all children". This shows how the transcripts of the workshops allow for conclusions about the connection between the confrontation with the observed sequences and the subsequent reflection in the interview to be drawn.

Based on Melanie Kuhn (2013), referring to Cloos (2001, 2008), the theoretical orientation of this project aims at the perspective of professionalization, since the discourse on early childhood education is more concerned with the theory of professionalization than profession (Kuhn 2013, p. 140). However, as Kuhn has pointed out, there is a desideratum regarding genuinely professional-theoretical empirical studies, specifically ethnographies, that focus on the everyday practices of educators. (Kuhn 2013, p. 143).

\footnotetext{
${ }^{2}$ This is the same principle Claudia Seele (2015) has worked out, namely the spatialization of pedagogical action. However, it is not the reference to monolinguality that constitutes the pedagogical space, but the translanguaging of those involved.
} 
Therefore, this training project is based on the scientifically substantiated discussion of daily practices in each educational context with the observed educators themselves. Due to the "closeness to practice and the focus on the outcome, such a project format has the potential to connect theory with practice and increase the overall quality of further education" (König and Friederich 2015, p. 14). This connection is also established by addressing the observed actions of educators within a workshop, stimulating reflection on one's own competences. According to Kuhn (2013, p. 144), promoting a more scientific and reflective practice that leads to an improvement in the quality of early childhood education is a recommended strategy of professionalization.

Thole et al. (2015) explained that pedagogical specialists who are confronted, for example, with video sequences from their own practice, view the situations directly in relation to themselves and their views (Thole et al. 2015, p. 129). However, the knowledge applied in the actions is not explicable ${ }^{3}$ (Thole et al. 2015 , p. 137). The project's format tries to counteract this aspect by enabling educators to generate theoretical knowledge based on their own pedagogical practices. Afterwards they may use this knowledge both for reconsidering their past pedagogical practices and consciously constructing new ones. This can reduce the aforementioned research desideratum concerning the reflection of pedagogical professionals on their own actions "as a necessary prerequisite for the development of a professional attitude" (Thole et al. 2015, p. 140).

\section{$5 \quad$ Outlook}

We regard pedagogical professionals in day-care centers and schools as actors jointly responsible for the implementation of language policies, since they act "at the local level" and in everyday pedagogical life as "language policymakers" (García and Menken 2010, p. 249). Through their practice they can question implicit language ideologies and norms as well as explicit or de facto language policy regulations and change their own strategies and practices when dealing with multilingualism. This is precisely the reason why they ask for concrete support from science and research.

Representatives from day-care centers and schools in Cologne that wanted to be involved in our research and professional training project were invited to the con-

\footnotetext{
${ }^{3}$ For this result, the analysis of the transcript of our first training course provides a counter-argument, but this must be addressed elsewhere.
} 
ference in Cologne-which is documented in this book-where they exchanged ideas with other scholars and educators about promoting social justice through translanguaging pedagogies in an international context by attending the lectures of Ofelia García and Kate Seltzer et al. (see this volume) and then the workshop of Claudine Kirsch and Claudia Seele (see this volume). After the conference, the first working meeting with the participants, on which we report here, was organized in order for the students of the University of Cologne to start their ethnographic studies in 2018. Both these future educators and the professionals working in practice and involved in the project are multilingual. With this project it is important to support and empower especially migration-related multilingual educators and teachers who, despite the official monolingual language policy in Germany, have set out to change their practice. In a further step, together with Claudine Kirsch from the University of Luxembourg and with the support of Ofelia García, we will set up a network with day-care centers and schools in New York to promote international exchange between interested educators, teachers and scholars.

\section{References}

Bogner, A., Littig, B. and Menz, W. (2009) (Eds.). Interviewing Experts. Research Methods Series. London: Palgrave Macmillan.

Bohnsack, R., Geimer, A. and Meuser, M. (2018). Hauptbegriffe Qualitativer Sozialforschung [Main terms of qualitative social research]. Opladen and Toronto: Budrich.

Charmaz, K. (2014). Constructing grounded theory (2. ed). Introducing qualitative methods. London: Sage.

Chilla, S. and Niebuhr-Siebert, S. (2017). Mehrsprachigkeit in der KiTa. Grundlagen Konzepte - Bildung [Multilingualism in day-care centers. Basics - concepts - education]. Stuttgart: Kohlhammer.

Cloos, P. (2001). Ausbildung und beruflicher Habitus von ErzieherInnen [Education and professional habitus of educators]. In: H. Hoffmann (Ed.), Studien zur Qualitätsentwicklung von Tageseinrichtungen [Studies on the quality development of day-care facilities] (pp. 97-130). Neuwied and Berlin: Luchterhand.

Cloos, P. (2008). Die Inszenierung von Gemeinsamkeit. Eine vergleichende Studie zu Biografie, Organisationskultur und beruflichem Habitus von Teams in der Kinder- und Jugendhilfe [The staging of common ground. A comparative study on the biography, organizational culture and professional habitus of teams in child and youth welfare]. Weinheim and München: Beltz Juventa.

Conteh, J. \& Meier, G. (2014). The Multilingual Turn in Languages Education. Bristol: New Perspectives on Language and Education.

Creese, A. (2017). Translanguaging as an Everyday Practice. In: B. Paulsrud et al. (Ed.), New Perspectives on Translanguaging and Education. Bilingual Education \& Bilingualism 108, 1-9. 
García, O. (2009). Bilingual education in the 21st century. A global perspective. Malden: Blackwell.

García, O. and Flores, N. (2012). Multilingual pedagogies. In: M. Martin-Jones, A. Blackledge and A. Creese (Eds.), The Routledge Handbook of Multilingualism (pp. 232246). New York: Routledge.

García, O. and Menken, K. (2010). Stirring the onion: Educators and the dynamics of language education policies (looking ahead). In: K. Menken and O. García (Eds.), Negotiating Language Policies in Schools: Educators as Policymakers (pp. 249-261). London and New York: Routledge.

García, O. (with Makar, C., Starcevic, M. and Terry, A.) (2011). Translanguaging of Latino kindergarteners. In: K. Potowski and J. Rothman (Eds.), Bilingual Youth. Spanish in English Speaking Societies (pp. 33-55). Amsterdam: John Benjamins.

García, O. and Li Wei (2014). Translanguaging. Language, Bilingualism and Education. New York: Palgrave MacMillan.

García, O. and Li Wei (2015). Translanguaging, Bilingualism, and Bilingual Education. In: W. E. Wright, S. Baun and O. Garcia (Eds.), The Handbook of Bilingual and Multilingual Education (pp. 222-240). West Sussex: John Wiley \& Sons.

García, O., Ibarra Johnson, S. and Seltzer, K. (2017). The translanguaging classroom: leveraging student bilingualism for learning. Philadelphia: Caslon Pub.

Geertz, C., Luchesi, B. and Bindemann, R. (1983). Dichte Beschreibung. Beiträge zum Verstehen kultureller Systeme [Thick description. Contributions to understanding of cultural systems] (pp. 7-25) Frankfurt am Main: Suhrkamp.

Jahreiß, S. (2018). Migrationsbedingte Mehrsprachigkeit in Kitas: eine empirische Studie zum Praxistransfer einer Weiterbildung für Erzieherinnen und Erzieher [Migrationrelated Multilingualism in day-care centers: an empirical study on transferring further training for educators into practice]. Münster and New York: Waxmann.

James, A. (2001). Ethnography in the Study of Children und Childhood. In: P. Atkinson, A. Coffey, S. Delamont and L. Lofland (Eds.), Handbook of Ethnography (pp. 246-257). Los Angeles: Sage.

König, A. and Friederich, T. (2015). Qualität durch Weiterbildung. Chancen für die Professionalisierung frühpädagogischer Fachkräfte [Quality through further training. Opportunities for professionalizing early childhood educators]. In: A. König and T. Friederich (Eds.), Qualität durch Weiterbildung: Konzeptionelle Denkanstöße für die Frühe Bildung [Quality through further training: Conceptual thoughts on early education] (pp. 9-18). Weinheim and Basel: Beltz Juventa.

Krumm, H.-J. and Reich, H.H. (2011). Curriculum Mehrsprachigkeit [Curriculum Multilingualism]. Münster: Waxmann.

Kuhn, M. (2013). Professionalität im Kindergarten. Eine ethnographische Studie zur Elementarpädagogik in der Migrationsgesellschaft [Professionalism in kindergarten. An ethnographic study on elementary education in the migration society]. Wiesbaden: Springer Fachmedien.

Li Wei (2011). Moment Analysis and Translanguaging Space. Discursive Construction of Identities by Multilingual Chinese Youth in Britain. Journal of Pragmatics 43, 12221235 .

Li Wei (2018). Translanguaging as a Practical Theory of Language. Applied Linguistics 39, 9-30. 
Lengyel, D. and Salem, T. (2018). Orientierungs- und Bildungspläne für die Kindertagesbetreuung [Orientational and educational plans for day-care]. In: I. Gogolin, V. B. Georgi, M. Krüger-Potratz, D. Lengyel and U. Sandfuchs (Eds.), Handbuch Interkulturelle Pädagogik [Handbook Intercultural Pedagogy] (pp. 441-445). Bad Heilbrunn: Klinkhardt.

List, G. (2004). Eigen-, Fremd- und Quersprachigkeit: psychologisch. [Own, foreign and cross-language skills: a psychological perspective] In: K.-R. Bausch, F. G. Königs and H.-J. Krumm (Eds.), Mehrsprachigkeit im Fokus. [Multilingualism in focus] (pp. 132138). Tübingen: Gunter Narr Verlag.

List, G. (2010). Frühpädagogik als Sprachförderung. [Early Childhood Pedagogy as Language Education] München: Deutsches Jugendinstitut e.V.

Montanari, G. E. and Panagiotopoulou, J. A. (2019). Mehrsprachigkeit und Bildung in Kitas und Schulen: Eine Einführung [Multilingualism and Education in Day-Care Centers and Schools: An Introduction]. Tübingen: utb Verlag.

Panagiotopoulou, A. (2013). Ethnographische Zugänge in der frühkindlichen Bildungsforschung [Ethnographic approaches in early childhood education research]. In: M. Stamm and D. Edelmann (Eds.), Handbuch frühkindliche Bildungsforschung [Handbook on early childhood education research] (pp. 770-786). Wiesbaden: Springer VS.

Panagiotopoulou, A. (2016). Mehrsprachigkeit in der Kindheit: Perspektiven für die frühpädagogische Praxis [Multilingualism in Childhood: Perspectives for Early Childhood Pedagogy]. München: Deutsches Jugendinstitut e.V.

Panagiotopoulou, A. (2017a). Mehrsprachigkeit und Differenzherstellung in Einrichtungen frühkindlicher Erziehung und Bildung [Multilingualism and doing difference in institutions of early childhood education]. In: I. Diehm, M. Kuhn and C. Machold (Eds.), Differenz - Ungleichheit - Erziehungswissenschaft [Difference - Inequality - Educational Science] (pp. 257-274). Wiesbaden: Springer VS.

Panagiotopoulou, A. (2017b). Ethnographische Zugänge zur Erforschung von Mehrsprachigkeit [Ethnographic approaches to the study of multilingualism]. In: M. BeckerMrotzek and H.-J. Roth (Eds.), Sprachliche Bildung - Grundlagen und Handlungsfelder [Linguistic education - basics and fields of action] (pp. 205-218). Münster: Waxmann.

Panagiotopoulou, J.A. and Rosen, L. (2018). Denied inclusion of migration-related multilingualism: an ethnographic approach to a preparatory class for newly arrived children in Germany, Language and Education, 32 (5), 394-409.

Panagiotopoulou, A. (2020). Inklusion und Migration: Zur Konstruktion von und zum Umgang mit ,migrationsbedingter Heterogenität ${ }^{*}$ in Kindertageseinrichtungen und Schulen. [Inclusion and Migration: Construction and ways of dealing with 'migrationrelated heterogeneity' in day-care centres and schools.] In König, A. \& Heimlich, U. (Eds.), Inklusion in Kindertageseinrichtungen. Eine Frühpädagogik der Vielfalt. [Inclusion in day-care centres. Early education for diversity] (pp. 73-89). Stuttgart: Kohlhammer.

Panagiotopoulou, J. A., Rosen, L. and Strzykala, J. (2020). Migrant Teachers Meet Refugee Students - An Ethnography of In/Exclusion in a Preparatory Class in Germany. In: A.-B. Krüger, L. Mary and A.S. Young (Eds.), Migration, Multilingualism and Education: Critical Perspectives on Inclusion. Bristol: Multilingual Matters (in press). 
Panagiotopoulou, J. A. and Zettl, E. (2020). Sprach(en)politik und Sprachpraxis in zugewanderten Familien und in Einrichtungen frühkindlicher und vorschulischer Bildung - Herausforderungen für pädagogische Fachkräfte [Language policies and practices in immigrant families and in institutions of early childhood and pre-school education - challenges for educators]. In: V. B. Georgi and Y. Karakaşoğlu (Eds.), Frühe Kindheit [Early Childhood]. Band 1. Reihe Migration, Diversität, Bildung. Stuttgart: Kohlhammer Verlag (in press).

Roth, H. J., Winter, C., Karduck, S., Terhart, H. and Gantefort, C. (2018). Mehrsprachigkeit im Elementarbereich. [Multilingualism in day-care centers]. Kita aktuell spezial. Mehrsprachige Frühförderung in der Kita [Day-care Centers Current Special. Multilingual Early Intervention in day-care centers] 1 (18), 28-31

Seele, C. (2015). Differenzproduktion durch sprachliche Praktiken. Ethnographische Beobachtungen zur Mehrsprachigkeit in luxemburgischen Kinderbetreuungseinrichtungen [Production of differences through linguistic practices. Ethnographic observations on multilingualism in Luxembourgish childcare facilities]. In: A. Schnitzer and R. Mörgen (Eds.), Mehrsprachigkeit und (Un)Gesagtes. Sprache als soziale Praxis in der Migrationsgesellschaft [Multilingualism and the (un)said. Language as social practice in the migration society] (pp. 153-174). Weinheim and Basel: Beltz Juventa.

Thole, W., Göbel, S., Milbradt, B., Rißmann, M. and Wedtstein, M. (2015). Wissen und Reflexion. Thematisierungsweisen pädagogischer Praxis in Kindertageseinrichtungen [Knowledge and reflection. Themes of pedagogical practice in day-care centers]. In: A. König, H. R. Leu and S. Viernickel (Eds.), Forschungsperspektiven auf Professionalisierung in der Frühpädagogik: empirische Befunde der AWiFF-Förderlinie [Research perspectives on professionalization in early childhood education: empirical findings of the AWiFF funding line] (pp. 124-143). Weinheim and Basel: Beltz Juventa.

Uçan, Y. (2018). Elterliche Arrangements frühkindlichen Spracherwerbs im Kontext migrationsbedingter Mehrsprachigkeit [Parental arrangements of early childhood language learning in the context of migration-related multilingualism]. In: E. Gessner, J. Giambalvo Rode and H.P. Kuhley (Eds.), Atlas der Mehrsprachigkeit [Atlas of Multilingualism] (pp. 241-257). Leipzig: Leipziger Uni-Vlg. 
Open Access This chapter is licensed under the terms of the Creative Commons Attribution 4.0 International License (http://creativecommons.org/licenses/by/4.0/), which permits use, sharing, adaptation, distribution and reproduction in any medium or format, as long as you give appropriate credit to the original author(s) and the source, provide a link to the Creative Commons license and indicate if changes were made.

The images or other third party material in this chapter are included in the chapter's Creative Commons license, unless indicated otherwise in a credit line to the material. If material is not included in the chapter's Creative Commons license and your intended use is not permitted by statutory regulation or exceeds the permitted use, you will need to obtain permission directly from the copyright holder.

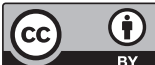

